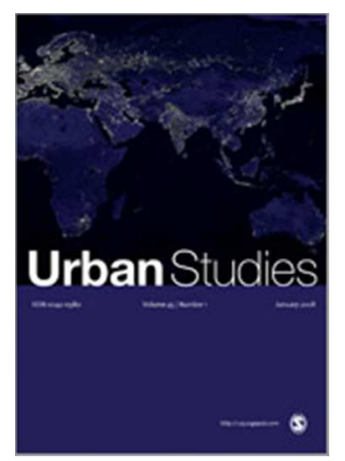

\title{
Politics/Matter: Governing Cape Town's Informal Settlements
}

\begin{tabular}{|r|l|}
\hline Journal: & Urban Studies \\
\hline Manuscript ID & CUS-812-16-09.R1 \\
\hline Manuscript Type: & Article \\
\hline $\begin{array}{r}\text { <b>Discipline: Please select a } \\
\text { keyword from the following list } \\
\text { that best describes the } \\
\text { discipline used in your paper.: }\end{array}$ & Geography \\
\hline $\begin{array}{r}\text { World Region: Please select } \\
\text { the region(s) that best reflect } \\
\text { the focus of your paper. } \\
\text { Names of individual countries, } \\
\text { cities \& economic groupings } \\
\text { should appear in the title } \\
\text { where appropriate.: }\end{array}$ & Africa \\
\hline $\begin{array}{r}\text { Major Topic: Please identify up } \\
\text { to two topics that best identify } \\
\text { the subject of your article.: }\end{array}$ & Governance \\
\hline $\begin{array}{r}\text { Please supply a further } 5 \\
\text { relevant keywords in the fields } \\
\text { below:: }\end{array}$ & Cape Town, Informal Settlements, Urban Governance, Material Culture, \\
\hline
\end{tabular}

\section{SCHOLARONE ${ }^{m}$ \\ Manuscripts}




\title{
Politics/Matter: Governing Cape Town's Informal Settlements
}

\begin{abstract}
Through the lens of South Africa's informal settlements, this paper explores the intersections between plans, practices, and materiality. These three arenas are each presented as uniquely agentic, contributing to plural configurations. In doing so, this work questions a prevalent tendency to frame governance/government solely as relationships between state and non-state actors. By reintroducing the agency and power of matter and materiality, not as adjunct or background, but as a critical technology of government and/in place, this work contributes to a growing debate within the (emerging) urban socio-technical systems literature.
\end{abstract}

\section{Key words}

Cape Town, Informal Settlements, Urban Governance, Material Culture, Poverty, Socio-Technical Systems

'You have come face to face with the hard reality of South African poverty: a dense forest of shacks, crowds of unemployed people milling on the streets, and attempts by some at smallscale commerce in makeshift shops. Men cluster in groups, throwing dice or playing cards. The place has the dull metal glow of aging zinc housing, the chaos of unpaved roads, the noise of a life lived in packed public areas, the smoke of smouldering braziers and the stench of sewage spilling into the streets'. (Harber, 2011: 2)

'The city will have to provide universal access to essential services, even to the poorest citizens who do not have a regular wage income, through the redistribution of finances. Apart from universal access to services, this will also provide access to other opportunities, such as well-located, serviced land, amenities and jobs'. (City of Cape Town, 2012:2) 


\section{Introduction}

Anton Harber's description of Diepsloot on the northern outskirts of Johannesburg speaks for many other informal settlements in urban South Africa. It alludes to the persisting precariousness and hardship faced by a very large number of poor black and coloured South Africans (and the immigrants with whom these precarious lives and livelihoods are shared) despite the formal end of Apartheid in 1994. In contrast, the extract from the City of Cape Town's five-year human settlements plan (2012-17) captures a state pledge to the poor that most governments in the South (and in the neoliberal North) seem to have abandoned. Across the world, the direction of travel seems to be towards one of minimal state protections for a growing poor population, who are left to the vicissitudes of the market, civic mobilisation, and NGOs.

South Africa is by no means insulated from these norms (McDonald, 2012). Yet the rhetoric of state obligations towards a nascent citizenry who are still awaiting the rights which democracy and freedom promised them remains strong. This is despite the fact that these rights - such as to housing, water, or democratic representation are daily traduced by new market inequalities and emergent power hierarchies, which lay over and reconfigure those of the past. This anomaly makes the politics of urban poverty management in South Africa - addressed here through the vignette of housing struggles in Cape Town - especially interesting. As we show, struggles for adequate housing are deeply conflicted. This is particularly so when explored through the interwoven themes of state programmes/policy, social practices, and material agency. These struggles are refracted through an assemblage of rhetorical, political, material, and operational dynamics which cannot be easily boxed as Keynesian, neoliberal, neo-patrimonial, or any other similar political descriptor.

The South African case - like state efforts in post-dictatorship Latin American countries - is important in a comparative perspective. This is particularly true given the extensive official neglect of the urban poor in most other developing economies. In sub-Saharan African cities in particular, the poor have largely been left to happenstance, self-initiative and the help of third-party organisations (Satterthwaite and Mitlin, 2014). In African cities, efforts to provide housing have often been aimed at the middle classes, failing to reach the urban poor entirely (Croese et al., 2016). South Africa, in comparison to most developing countries, takes seriously its constitutional obligation to provide the urban poor with housing, as well as free or affordable water, electricity and sanitation on a private or shared basis (Pieterse, 2014). Since the fall of Apartheid, the supply of basic services (and housing) has become a key measure of the new nation's commitment to the poor. It has also become the grounds of dispute between public authorities seeking to deliver while constrained by the scale of need and available finance. There is, therefore, substantial room for insight to be drawn, in particular for middle income countries attempting 
redistributive and spatial policies amidst complex material and political constellations (Hellar, 2012; Gilbert, 2004).

While almost four million houses have been built by the state, there remain millions waiting in backyard shacks, informal settlements, overcrowded accommodation and hijacked inner city buildings for the state to provide. That twenty years after the fall of Apartheid the poor continue to wait for the state to provide housing may occasion surprise or consternation. This waiting could prove without end (as is widely accepted in South Africa), yet this obduracy could simultaneously be seen as a powerful refusal by the poor to give up their right to rights (Oldfield and Greyling, 2015; Mafukidze and Hoosen, 2009). If the language of 'waiting for the state' rings an anachronistic note in a neoliberal age, a convincing case remains to be made to prove that markets and civil society can deal with the needs of some two billion people expected to be living in slums by 2050 (UN Habitat, 2008). The dynamic of state provisioning in South Africa could prove to be illuminating in this regard ${ }^{1}$. The South African experience is symptomatic of a state-led model of poverty reduction, one that could be judged as key in addressing the large-scale grim slum futures that the urbanised world confronts (UN-Habitat, 2012; Baker, 2008), or as an expensive and cumbersome model that has outlived its use..

What we term 'the RDP/BNG housing policy regime' has been criticised across the country on many grounds: the unsustainable sums of public expenditure involved in building the settlements; the poor quality of materials used; the corruption of the contractors; the blandness and isolation of the settlements; the proliferation of backyard shacks for rental income or additional space (because the pitched roofs prevent upward build); the no-sale period of eight years that stops people from moving to jobs elsewhere or encourages the illegal exchange of titles; the long and uncertain period of waiting for housing; and the rigid eligibility criteria that still exclude swathes of the poor living precariously (Harrison, Todes and Watson, 2008; Ross, 2010; Khan and Thring, 2003; Turok and Borel-Saladin, 2015). There is no shortage of academic and public commentary on the short history of post-apartheid housing policy and its discontents (Van Donk et al., 2008; Harrison et al., 2007; Huchzermeyer, 2011; Cirolia et al., 2016). The contribution of this paper lies in its attempt to place the state housing response within its lived, practiced and material context. There exists analyses of the housing policies and the mobilisations of the poor and their advocates, by intermediaries and strongmen, and by political, business and civic organisations (see, for example, Harber, 2001 and Sacks, 2014). But the analysis of state activity through the prism of these mobilisations - how it is accompanied, inflected, improvised, (in)formalized, or displaced on the ground and by matter - remains relatively thin.

\footnotetext{
1 This is not to place South African housing policy on a perch. In fact, there is a live debate in South Africa on the viability of ownership-oriented state provisioning for the poor (Huchzermeyer, 2011; Bond and Tait, 1997; Parnell and Robinson, 2012).
} 
However, there is a growing body of work on South African low income settlements which specifically responds to the wider literature on informality, improvisation, and materiality. This literature works to involve intricate governance and material arrangements alongside or in the gaps of state intervention. For example, McFarlane and Silver (2016) discuss social mobilization in Cape Town around sanitation and the use of a particular material - human faeces - as an agentic actor in political struggles. Von Schnitzler (2016) discusses the techno-politics of and resistance to prepaid water meters in townships in Johannesburg. Ernstson (2013) dissects natural ecosystems as 'material symbiotics' playing out between an important nature reserve and a huge housing project on Cape Town's flatlands. In a particularly useful contribution, Dierwechter (2004) studies how social life in a Cape Town township is shaped by its spatial layout and the geographies of informal trading; the former's Apartheid and post-Apartheid placements affecting life chances, and the latter's infrastructures between urban farms and food stalls playing their part in shaping entrepreneurial fortunes and the availability, price and consumption of fresh food for local residents. Dierwechter shows that township infrastructures, from the topography and aesthetic quality of the built environment to the roads and materials of trade, are not just the ground on which social life is conducted, but are key technologies of social organisation and experience: governing matter. The qualities of this matter and the politics of conduct underpinning them (i.e. planning rules, cartographic expertise, design decisions, controlling parties, social battles over provisions, hidden rules and rituals of access and allocation) are actively involved in the making of everyday life and social prospects.

To envisage infrastructures in this way, following the analysis in urban political ecology of metabolic systems as socially discriminant (Heynen, Kaika and Swyngedouw, 2006; Gandy, 2014) and in 'assemblage urbanism' of trunk infrastructures as hybrids of human and nonhuman interdependence (Simone, 2014b; De Boeck and Baloji, 2016; McFarlane, 2011; Scheba, 2014) is to acknowledge that the technologies of government include much more than formally and informally-organised social power (see Truelove, 2015, for a treatment of the politics of water in Delhi's informal settlements along these lines).This is clear from a body of writing on urban infrastructures as political technologies, alluding not only to the terms of supply (the tariffs, conditions, providers and gatekeepers that govern the availability and distribution of water, electricity, sanitation and other public goods) but also to the agency of the infrastructures themselves (complete or incomplete, maintained or neglected) in moulding social practice and collective culture (Larkin, 2013; Gandy, 2014; McFarlane and Graham, 2014; Amin, 2014; Truelove, 2015; Simone, 2014b). Writings based on detailed case studies, by Robert Neuwirth (2005), Abdoumaliq Simone (2014a), Ananya Roy (2011), Filip De Boeck and Sammy Baloji (2016), Colin McFarlane (2012), David Satterthwaite and Diana Mitlin (2014), James Holston (2008), Teresa Caldeira (2000) and Bryan McCann (2013), to name just a few of the protagonists, show how networks of non-state actors, including technologies 
and infrastructures, are implicated in the making and maintenance of slums and poor urban neighbourhoods.

Some of these authors draw on an evolving body of work which might be termed 'urban socio-technical systems' (Amin and Thrift, 2016). While much of the older socio-technical systems work sits in management or transition studies, newer work, within which we find inspiration, builds on the seminal work of Graham and Marvin (1996; 2001). However, it adapts this work to speak with and from southern contexts. Jaglin (2014), for example, discusses 'heterogeneous dispositifs'. Simone (2008) speaks of the 'politics of the possible' and Coutard and Rutherford (2016) speak of the 'post-networked city'. This work is no apology for the non-state governance of informality. Instead it is a reappraisal of possibility and propositionality, including public policy reforms refracted through, and perhaps aided by, things already in place. Its approach has much to add to the debate on state welfarism in South Africa, by identifying potential interlocutors and allies, the labour needed to embed and sustain policy interventions, and the social agency of mundane matter and organisation.

Accordingly, this paper begins with a discussion of state settlement policies for the poor in Cape Town. The institutional field is found to be less at loggerheads than in the past, with the authorities increasingly recognising the need for variegated approaches and collaboration with non-governmental actors. Regardless, the achievements of public policy are considered far from adequate, constrained by policy choices and inertia, resource limitations, the deep spatial and racial cuts of Apartheid, rising housing demand due to persistent migration into the city, and market selections systematically discriminating against poor black South Africans. The size of the gap between housing supply and demand and the obduracy of impediments in the way of the poor suggest that city-level policies, however reformed and joined up, will be unable to address the settlement needs of the poor in Cape Town.

That said, it is not as though existing settlements, old and new, are inert spaces, even if the expectation of state provisioning remains high. They are living communities with their own governance arrangements, which substitute for or mediate public interventions (Jurgens et al, 2013; Bénit-Gbaffou and Oldfield, 2011; Skuse and Cousins, 2007; Pieterse, 2013; Sacks, 2014). These arrangements may not necessarily work for those most in need. The challenge of local level power dynamics, sketched out in the section on Practices, echoes the findings of ethnographies of informal settlements around the world which show how gangs, strongmen, elected and selfappointed leaders, businesses, religious and civic associations, and more, vie with each other for influence and control, often at the expense of the poor (see, for example, Truelove, 2015; McCann, 2013; Boo, 2012; McFarlane, 2013; Björkman, 2015; Hansen, 2012; Lancione, 2015). Similarly, sorts of 'governance from below' configurations in Cape Town's settlements may well subvert municipal interventions 
and constrain community-oriented schemes. However, they cannot be ignored as they are the substrate through which policy reforms must pass.

Importantly, the material infrastructure of informal settlements is another substrate with considerable authority and influence over lives and livelihoods. This is brought to the fore in the section on Materials. Following studies of the social agency of mundane urban matter (see Amin, 2014), this section examines how Cape Town settlement infrastructures act as political agents, their political economy and materiality actively involved in shaping social wellbeing, expectation and opportunity. The forms of agency observed in the second part of the paper, from the fragile labours of charismatic individuals to the hidden convocations of trunk infrastructures, decentre the traditional conceits of urban governance, and press for policy reflection on the ways in which social enthusiasm but also so-called dead matter can be made to work for the poor.

The final section of the paper discusses the prospects moving forward. Here we discuss first the propositions for the South African housing policy regime foregrounded through this study of programmes, practices and matter. This is most obviously of interest to those working on housing in developing cities. We conclude with a discussion on the implications of this framing for urban theory more generally.

\section{Programmes}

Du Noon, Nyanga, Marikana, Delft, Blikkiesdorp, Flamingo, Lotus Park are the evocative names of some of Cape Town's many poor neighbourhoods (Fig. 1). Mixes of old Apartheid townships, more recent subsidised-housing projects, serviced shack settlements, and the most flimsy structures of illegal occupation, they house the majority of the city's historically disadvantaged black and coloured population. ${ }^{2}$ They are also arrival areas, providing accommodation for migrants arriving in the city from the Western Cape, other provinces, and the rest of the continent. They represent the city's continuing geography of housing and service shortage, social deprivation and exclusion, crowding and spatial segregation, existential uncertainty and danger, abjection mixed with enterprise, long-distance labour, and racial and class inequality. They are the sore and sustenance of the 'beautiful city', the measure of the capacity of the city - and South Africa in general - to deliver the fair and equal society (Bond, 2000; Newton, 2009). They are the spaces of explicit policy, planning, and programme attention ranging from intentions to evict or reconstruct to intentions to upgrade or empower (Cirolia et al., 2016).

The housing policy regime of Cape Town must be explored within the context of South Africa's national housing delivery programme (mentioned above). South Africa's housing delivery programme, known colloquially as RDP or BNG housing after the Reconstruction and Development Programme of 1994 and the Breaking

2 Both Coloured and Black African are official 'population groups' as per the South African Census. 
New Ground human settlements policy of 2004. There are some notable differences between RDP and BNG housing. Most particularly, the size of the units (the latter being much larger) and concerns over the integration of subsidized housing with social and economic amenities. However, the similarities and inertia between the two policy agendas undermine the often rhetorical differences. For example, most informal settlements upgrading projects or integrated residential development projects practically depart very little from the conventional RDP delivery style (Cirolia et al., 2016; Huchzermeyer, 2011). It is sufficient to discuss the RDP/BNG policy regime as a continuation of an approach beginning in the early 1990s.

\section{Insert Figure 1 here}

\section{Fig. 1 Cape Town Townships, Informal Settlements and Study Sites}

In some ways, the RDP/BNG approach appears similar to the 'site and service' delivery approach which was pushed by the World Bank in many developing countries in the 1970s. It involves the delivery of serviced plots in large projects. However, in South Africa the poor did not pay for these plots (Wilkinson, 1998). They were given free of charge to 'the poorest of the poor'. In addition, and unlike the conventional 'site and service' approach, a housing unit was provided on the site, the specifications of which have increased gradually over time. The decision to provide a unit was a clear response to the local context and experience. On the one hand, the previous site and service projects of the early 1990s had largely been viewed as a failure, with few households successfully developing their sites (see Nuttal, 1997). On the other, the new (and very progressive) constitution secured the right to shelter, the interpretation of which negated the possibility of simply providing a site.

The RDP/BNG regime is a huge machine which, once set in motion by grants and delivery targets, has a life of its own. Large-scale funding is deployed by the national government and allocated to the provinces for housing subsidies in the form of a 'conditional grant' (the amount of the subsidy and other qualifying criteria are set nationally). The province then sets to work implementing this national policy, dividing the pot of money between the many housing delivery programmes and the towns and cities within its jurisdiction. In the Western Cape (the province within which Cape Town is located), the vast majority of the housing budget goes to develop RDP/BNG housing. This is to say, it goes towards the development of serviced sites and housing units which are transferred, free of charge, to low income households. The majority of the provincial budget (around 70\%) is allocated to the City of Cape Town, either directly or through provincial projects. In many ways, the delivery of housing in Cape Town has been the de facto planning policy, actively sprawling the city and pushing its urban edge across the Cape Flats, leaving the other departments (such as planning, education, and health) to scramble after the new developments (Pieterse and Cirolia, 2016). 
The unsustainability of this delivery system has not gone unnoticed by officials, politicians, activists and academics. There seems to be recognition that the regime may be an effective provider of housing but is producing cities which do not function, creating unbearable costs for the urban poor and the municipality alike. This is made clear in the county's National Development Plan (2010), Integrated Urban Development Framework (2014), City Support Programme (a Treasury programme launched in the late 2000s), and a whole range of Western Cape and City of Cape Town report and frameworks. There is a recognition that the regime is in crisis.

Nowhere is this clearer than in the City of Cape Town's 2012-17 Strategic Plan on H Human Settlement. It is estimated that over 20 per cent of households live in the city's 450 'informal settlement pockets'. In a city of 3.8 million people, this number of 'pockets' (continuously inflated by new and illegal land occupations) and these proportions (which exclude the large number of illegal 'backyard' shacks put up for extra rent in state provided housing plots) pose a significant policy challenge. For the city, this is a challenge of numbers - of new build 'sites' and 'top structures', land preparation, settlement upgrading, installation of utilities and services, and maintenance and repair. It is also a challenge of territorial management and spatial integration. The logics of the city work to prevent further sprawl and environmentally costly development, ensure the infrastructural and fiscal integration of the settlements into the metropolitan area, and overcome the persistent 'apartheid spatial structure'. For all the constitutional and political commitment to the casualties of Apartheid, these challenges are not going to be overcome easily or quickly - a fact hinted at for the first time in the strategic plan's acknowledgement of the value of a diversified, multi-actor, and connectivity-based approach to human settlement.

The shift from 'government delivery' to 'governance arrangements' is an important policy shift (Cirolia et al., 2016). This requires necessarily including the work of community groups and the private sector in the provision of housing and human settlements development. The City, in its strategic plan and elsewhere, explicitly recognises the value of a plural and collaborative approach to human settlement, sensitive to the often-disabling shadow cast by the state, the scale of the problem faced, and NGO criticism of state remoteness and procedural rigidity. The City is keener now than before on harnessing the initiative of NGOs, increasingly considered as 'development partners' with detailed on-the-ground knowledge of settlement dynamics.

The status quo of housing delivery and city building is further troubled by the explicit move towards incrementalism. This shift can be seen in the push for public-sphere upgrades in informal settlements, the extension of services to 'backyard shacks' located on council property, and other city projects. This thinking in line with policy practice in other countries committed to the poor, aims to ensure that the poor have access to land, trunk infrastructures and basic services, and allows residents to construct their own houses or participate in a fair and active rental market (Roy, 
2005). A further and important shift (though somewhat at odds with the abovementioned interest in incrementalism) is the argument for densification and urban compaction, which is mentioned in the plan. Multi-torey BNG housing (such as in Joe Slovo's N2 Gateway Project), Urban Development Zones (UDZs) and other new instruments and practices reflect this thinking.

Private sector and community involvement, incrementalism, and densification - while not uncommon policy objectives - are radical departures from conventional RDP and BNG housing. Thus the strategic plan envisions Cape Town as a city of multiple growth nodes serviced by an efficient and integrated transport system that will enable informal settlements to be connected to proximate nodes instead of only one, increasingly congested, city centre. The current institutional restructuring of the City of Cape Town (which has resulted in the Transportation Department at the reigns of a new Transit Oriented Development Strategy) is a response to the dysfunction of lowdensity sprawling development, characteristic of RDP/BNG regime.

Despite this ambitious and controversial restructuring, there are many factors fixing the system in place and militating against the possibility of its overhaul or reconfiguration. The most important is the 'target chasing' performance, which forms part of the annual auditing practice. Both the national government and the Province set quantitative delivery target which become the fixation of compliance-obsessed officials and ambitious politicians. These targets drive officials to deliver as quickly as possible (on the cheapest possible land), regardless of the long-term costs. The other powerful element is the incredible mistrust and hostility which has accrued between poor urban dwellers and the state. This tension results in residents, as well as their elected and non-elected representatives, hijacking or blocking projects until particular demands are met. These demands tend to follow the familiar, rejecting that which is seen as subpar (such as alternative infrastructure or building technologies). The implications of both pressures are that creativity and change is discouraged and even rejected and policy intentions remain 'good practice' rhetoric.

Despite the deep challenge of reconfiguring a path-dependent machine, two important programmes give life to the city aspirations and have, in many ways, become icons of a new way of doing housing in the city. Violence Prevention through Urban Upgrading (VPUU), led by a German-funded NGO, is one such initiative. Through sustained involvement in the settlements it selects, VPUU tackles social breakdown and deprivation though a programme of public works and community empowerment. In fact, it explicitly rejects any intervention into housing or engagement with housing departments, preferring 'area-based' public investment frameworks which align with Cape Town's current Spatial Planning and Land Use Management Department. Its ventures, whose outcomes are closely monitored by the organisation, are widely considered to be successful, imaginatively investing in public 
spaces as sites of security and social involvement ${ }^{3}$. This could be a multipurpose building in a central public space that doubles up as watchtower, meeting place, and educational and information centre ('Active Boxes'). Or it could be redesigned public spaces around shared water taps where mothers, outreach workers and infants gather daily for water collection (Ngxiza, 2012; Watson, 2012). With its strong emphasis on community empowerment, VPUU initiatives are overseen by local committees drawing on representatives from different sections of the community, in pursuit of decisions that are deliberative and democratic and in the hands of a capable local leadership. According to their team, VPUU is as interested in the policy process as in the outcomes, and accepts that decisions may take a long time, lack in expert judgement, and sometimes get things wrong. It does not shirk from the slow and experimental nature of social learning, and indeed, remains wary of blanket and top-down policy interventions.

Another well-established NGO that focuses on community-led infrastructure improvement is the Community Organisation Resource Centre (CORC), affiliated to the well-established global alliance Slum Dwellers International (SDI) (Ley, 2010; Bradlow, 2015). CORC focuses on 're-blocking' shack neighbourhoods by thoroughly upgrading their water, electricity and sanitation infrastructures and their streets, pavements and public spaces. It proposes a redesign plan to a settlement and only proceeds if the plan is approved by residents, who must also agree to cover 20 per cent of the cost of the redevelopment through savings. The rebuilding of shacks is left to residents, while CORC often advises on design, materials, and suppliers. Often CORC struggles to get its proposals approved because communities are divided, lack effective leadership, are wary of committing to a financial contribution, and most importantly, expect the state to deliver free housing. Many communities have rejected CORC's strategies and efforts (in particular the mandatory savings schemes and timeconsuming self-enumeration). As one resident stated with disgust if we work with you all, we have been told [by our ward councillor] that we will move to the bottom of the [housing waiting] list'. However, when a re-blocking plan does proceed, as it has in a small settlement called Flamingo the results can be transformative. Flamingo has all the orderliness of a serviced settlement. Its residents have spent their own money to purchase a high quality and fire resistant Inverted Box Rib material. They have supported the women who worked closely with CORC who have emerged as community leaders, and they possess both hope in the future and a strong sense of place. In one of the leader's home, maps and images of the settlements 'before' and 'after' hang on all of the walls as testament to their success. These may be fragile achievements, for newness weathers, resources run out, social agency thins, and leaders tire, yet the contrast with the many more settlements in Cape Town where the poor continue to live in dire conditions, waiting in vain hope for improvement, is unmistakable.

\footnotetext{
3 There have been some critiques of the VPUU approach, in particular, concerns around crime reporting, transparency, and the long and drawn out models for public engagement. These concerns are largely documented in the grey literature.
} 
There are many actors involved in the formal politics and provisions of settlement development in Cape Town. The dominant state-led approach - focusing on new build, home ownership, and basic services for the poor - is being nudged in new directions by an approach advanced by NGOs and community activists privileging diversity of tenure, in-fill and in-situ upgrading, and social mobilisation. It would appear - at least from the language of the City's strategic plan and the growing number of meetings between policy practitioners - that consensus is emerging around the need for a plural approach towards Cape Town's settlement challenges. A recognition of progressive trends in Cape Town's policy regime does not diminish the criticism of RDP and BNG housing generally or even of these 'innovative projects' in particular. Neither is it meant to underestimate the huge gap between policy rhetoric and institutionalization of innovative and progressive practice. Criticism is valid for Blikkiesdorp, a faraway camp close to the airport, which like so many other 'temporary resettlement' areas has the feel of permanence - its desolation, deprivation and malfeasance crying out for organised initiative unblocked from restrictive state procedure. So too is it necessary to account for the city's RDP housing estates in which state provisions have been uniform, rudimentary and poor quality, and for countless shack settlements such as Lotus Park likely to wait a long time for public services and housing from a municipality inundated with demand.

But the criticism which has been so central to South African urban scholarship also needs to acknowledge that the 'slow and rigid procedures' have secured free housing and services for a substantial number of poor Cape citizens, and are now accompanied by targeted interventions such as those in Du Noon where the planning authorities have returned to improve public spaces and services, with a keen eye on preserving informal practice. In turn, it is not as if the NGOs and social movements offer comprehensive coverage. The NGOs, for example, favour particular policy choices (e.g. re-blocking, local leadership, public spaces), their actions are restricted to particular places and by resource constraints, and their wider influence depends on a campaigning capacity that is not always strong. The pro-poor social movements are no different. If the People's Housing Association played an important role in supporting the occupation of Symphony Way by 150 families facing eviction in the adjacent settlement of Delft - an occupation that produced a strong community governed by the residents - it was still unable to prevent the forced removal of the families some 18 months later to Blikkiesdorp or their disintegration as a collective in this large, impersonal and divided settlement. Similarly, for all the help provided by ANC-affiliated Ses'kona to the residents of another occupation - Marikana - to selforganise so as to avoid eviction, the route of direct democracy is fragile, troubled by the harsh circumstances and inexperience of the settlers, the serendipities of leadership, the difficulty of sustaining this form of agency, and the constant wait for activists and professionals who might be able to help. Community mobilisation clearly does not always produce tangible gains and cannot be romanticized. 
These limitations may be tempered in a plural institutional field, and it is probably true that Cape Town offers many more pro-poor initiatives and actors than most developing country cities. Yet a large gap remains between the City's ambitious plans to provide universal access to services and the situated efforts of NGOs and social movements (Cirolia, Smit and Duminy, 2015). In part, this is a problem of mismatch between high public expectation and what the state can realistically deliver. The City and other actors confront a reality of continued mass migration into the city, prime locations being passed over to high-yield investors and residents, settlement residents enduring long and expensive journeys to access work and welfare, people waiting interminably for state housing or relocation into semi-serviced land, insalubrious and risky conditions in ever proliferating shack settlements and land occupations by the homeless, and a market economy biased against those without means. The City's plans - and the South African institutional field in general - have some way to go in order to better manage migration into the city and mobility within it, protect inner city and prime locations for mixed use and mixed communities, rapidly develop shack settlements and resettle backyarders, unblock and regulate a housing rental market to complement or replace the current commitment to free housing owned by the poor, facilitate NGOs to extend their reach, and embark on a model of economic growth based on social inclusion, income redistribution and universal welfare. Much of this sits uneasily with a neoliberal political economy pledged to interests that promise the highest economic returns

\section{Practices}

Prospects in Cape Town's settlements do not depend solely on the formal institutional environment - the amalgam of laws, rules and policies of the public authorities, NGOs and social movements. Like their equivalents elsewhere, the settlements, from illegal occupations and serviced or non-serviced shack areas, to the older townships and newer subsidized neighbourhoods, have their own rituals of governance. The settlements are not inert places waiting to be enlivened by external interventions. Instead, they have their own force field made up of the material arrangements of habitat, the repetitions of daily life, the words and actions of figures of authority or force, the sedimentations of collective culture, the jostle of organised interests. This force field is as much part of the structure of government as are the plans and projects of external actors - challenging, bypassing, and modifying them as Harber shows for Diepsloot through his analysis of diverse vested interests, social groupings and strongmen.

Returning to Lotus Park, VPUU's efforts in building an effective and inclusive local leadership, developing empowerment programmes, erecting a multi-purpose Active Box made of stacked shipping containers, and reclaiming public spaces are undoubtedly important and potentially transformative interventions. Yet, in the backstreets of crowded and dilapidated structures, where there is little public space, and grey water everywhere, these creative and colourful interventions seem distant. 
These efforts are blunted by the social force of shebeens plying alcohol, a prevailing culture of disenchantment and resignation, the criminal economy and its gatekeepers, vigilante justice and the public expectation that sooner or later the state will provide free housing. The local recycling depot - directly across from VPUU's container - is run by a feared gangster, known in the community for a ruthless approach to his business. A local VPUU member explained that a vacant plot which looked like it could be a public space was, in fact, the site of a home which had been burnt down by the community after the son stole a cell phone. She went on to explain 'I will not improve my shack now as it would be unfair to the others around me who must wait for the city to do it'. Beyond the VPUU efforts, these practices have huge effect on the daily life in the settlement.

In the areas of rudimentary formal support, such as the temporary resettlement areas of minimal public investment (known as TRAs), this kind of social force is increasingly visible. This is so, for example, in bleak and remote Blikkiesdorp, its sea of state-built corrugated iron boxes and narrow passages hiding the rudimentary public services installed by the municipality. The conditions here are so challenging, it has inspired popular outcry and creative non-fiction (Steinberg, 2014) ${ }^{4}$. The social anomie, resentment and uncertainty over whether the promised move to "proper housing' will ever materialise plays into the hands of gangs, religious groups and strongmen governing the balance between hope and despair, tempering the efforts of NGOs and social movements and crushing the efforts of families trying to build community. It is striking that in one section of Blikkiesdorp live many of the families that mobilized and occupied Symphony Way to avoid eviction. Then, the small community was a tightly knit and effective group with strong leadership that resisted the authorities, publicised its cause, and secured the wellbeing and safety of its residents. However, in the vast stretches of matchbox structures and sandy lanes, the group and its influence have simply melted away or been systematically dismantled by the harsh material conditions.

The juxtaposition and messiness of formal and informal authority and practices are clearly evident in the more established settlements. In Du Noon, for example, 15 years after government subsidies went to upgrade the squatter settlement, the efforts of the municipality to improve trunk services, reclaim and upgrade public spaces, and encourage an effective structure of ward representation, jostle with other forces of influence. These include the practices of informal governance in the adjacent shack settlement spilling into Du Noon, the many NGOs working in the area in different ways (from encouraging savings schemes to facilitating schooling and childcare), the vibrant and variegated commercial sector vying for space and influence, and the owners of two-story buildings who provide 8X12 ft rental units but ignore building lines in an effort to maximize coverage and income (McGaffin et al. 2015; Wolff, 2010).

\footnotetext{
${ }^{4}$ See the following article in the Mail and Gardian (http://mg.co.za/article/2010-06-07-its-like-aconcentration-camp)
} 
In the city's older townships - once heavily policed and still bearing the mark of black marginalisation and segregating Apartheid design - the pluralities are even more pronounced. Nyanga is one of Cape Town's oldest townships (Bickford-Smith, Van Heyningen et al.,1999). Take Makondo Square, alone, with its 300 informal shacks built since the early 1990s on a wetland behind Nyanga township's first military houses and a line of RDP housing. It lies within walking distance of backyard shacks, converted Apartheid hostel blocks, and the township's trunk roads and crossroads brimming with buses and taxis, street life, commerce, and entertainment. Its uniformity, manifest in a lack of community, services and amenities, shared hardships, the numbing wait for resettlement, a rote ward committee, and a precarious built environment, conceals many differentiations of force. There are the gangs and their rackets that force local youths to enrol despite their wishes, pushing back at safe-street campaigns. There are the churches and their pastors competing with each other for influence, fragmenting the neighbourhood into communities of belief and entertainment, mustering enthusiasms that stop just short of political mobilisation. There are festering tensions between the DA-branded projects which spring up to address community safety and the ANC-aligned South African Police Department, located in a painful irony on Great Dutch street. There are the acts of violence, spontaneous and organised, that caution against mobilising for change. There are the many lives led in networks of association that stretch beyond Makondo and Nyanga, making the Square more of a crossing than a bounded community. There are all kinds of ways in which individual households alter the landscape through their own initiative, including small acts of piracy to secure essential services such as water and electricity.

One consequence of this kind of plurality is that life hovers around the status quo. Powers old and new fight for interstitial space. Any impetus for change has to pass through many visible and hidden collectives that temper, mediate and challenge initiatives. Coalitions that require time, energy and resource are hard to find, often operating to fragile micro publics which exist only ephemerally. Much conspires to keep things as they are because of the fine balance of force between organised interests even when settlement life appears quiet and uneventful. For example, in Makondo Square, a dense, mixed housing solution to accommodate diverse squatters and officially-recognised residents makes sense, all the more so because the CORC expert who led the regeneration of Flamingo and other similar places is from the neighbourhood, and offered to work with the community on an SDI Development Action Plan that in all probability would be funded. But the proposed changes challenge the vested interests behind the status quo and require a momentum of grass-root organisation and determination that would be contested. The politics of the status quo favours inertia, keeps people clinging to the hopeless expectation of free housing instead of gathering behind an alternative that offers a tangible housing solution. 
This kind of perpetually reconfigured stasis is common in long-established townships and informal settlements, be they in Cape Town or beyond. Momentum for change often comes from dedicated individuals and organisations working silently and diplomatically. They work in the background, delicately working through embedded and territorialized interests. One example in Nyanga is a 'theatre for change' initiative, Poppiehuis, founded and led for many years by Professor Vava, its charismatic and dedicated playwright/director inspired by Augusto Boal's (1998) principles of the 'theatre of the oppressed'. Poppiehuis offers performances by local residents for the community at large. Staging immaculate plays on controversial local issues such as domestic violence or substance abuse, the theatre has provided a lifeline to Nyanga youths, many of whom still hide out in the cool backrooms of the community centre to avoid hot and busy public spaces. While much attention has been given to 'service delivery' and 'infrastructure', such efforts demonstrate the power of softer and less material intervention. . Another example is a crèche - like many crèches in South African townships - run out of the cramped home of a local resident. However, in contrast to many, this principal is determined to equip the many pre-school children she cares for with basic English skills so as to give them a surer start in life. The crèche exudes the vibrancy and optimism of its founder, who worked as a teacher and in film and photography and invested her own resources and sponsorships from diverse educational trusts to build this small but significant social enterprise. Elsewhere too, the presence of resolute, dedicated women turns out to be pivotal: .Fatima ${ }^{5}$ finding the food, space and resources to give the Muslim children of Blikkiesdorp one warm meal a day in her Madrassa. keeping alive the solidarity that dissolved soon after her family's' move to Blikkiesdorp (Symphony Way Pavement Dwellers, 2011); Marlene and her two friends in Flamingo persuading the residents to sign up to the CORC-led refurbishment of the neighbourhood, securing their financial contributions and compliance with the agreed housing standards, and overseeing the success of the refurbishment and the upkeep of public spaces and infrastructures.

As these cases show, there is an under-acknowledged element of social organisation individual leadership - that needs to be recognised in explaining change in the informal settlements. It seems that in the gap between people waiting for the state to provide, NGOs intervening with specific projects, and local organised interests exercising their power, the success of community welfare projects rests disproportionately on the daily practices of exceptional individuals operating out of fragile spaces that they have tirelessly curated. The kind of solidarity that the squatters of Symphony Way managed to forge and sustain to fight eviction is uncommon, deflected by local institutional spikes, a sense among the poor that they will eventually receive state housing, and the trials of individual survival. From time to time, social movements manage to mobilise communities, especially during new land occupations and over specific grievances such as poor sanitation, but this is inconsistent. The fragility of grass-root mobilisation is not reducible to creeping

5 The names of individuals have been changed to protect their identity. 
neoliberal individualism in South Africa. Perhaps when the teenage children of successful families in Makondo Square speak of doing well for themselves first and then giving back to the community in an individual capacity, there is the tinge of a new consumerist culture of self-advancement (Posel, 2010). Alternatively, their stance might reflect the awkward truth that the politics of the social in the settlements veers towards the dedicated individual because it operates on a closed ground - closed by vested interests, official interventions, everyday struggle, and social expectation that the state will provide.

\section{Materials}

There is an important third element of governance in addition to the formal programmes and social activism we discuss above, increasingly acknowledged in South African writing as part of the institutional environment of informal settlements. These are the social allocations and cultural tracings of the material and aesthetic infrastructure. Amidst high expectations of post-Apartheid reparation, infrastructures and matter tend to be understood as the objects and not agents of government. Echoing the work of McFarlane, Scheba (and others) and drawing on observations in Nyanga, Lotus Park, Blikkiesdorp, Flamingo, Du Noon and Marikana, we explore the possibility of material agency. From this perspective, it is clear that built aesthetic and material infrastructures are implicated and agentic in the governance of lives and livelihoods. To foreground this argument, we discuss the power of distance, aesthetics of place, landmarks, material flows, and the politics of infrastructure.

Most obviously, the cartography of settlement - fixed in many ways by the Apartheid legacy of spatial confinement and distancing - lingers as a key determinant of social prospect. It is clear here that physical distance has its own power. The majority of informal settlements and townships are miles away from the city centre, in places offering few work opportunities and social services, with poor transport connections. The financial and temporal implications of being physically moved long distances every day (or whenever one can find work) falls heavily on the urban poor who spend larger proportions of their income and many hours a day moving back and forth from the periphery to the core of a sprawling urban fabric. The City's plans to develop an integrated transport system and multi-nodal economy (as per the TOD plans discussed in the earlier section) may ease the spatial marginality by making transportation faster and cheaper. However, Bus Rapid Transit systems (unlike other more capital intensive investments) rely heavily on operational subsidies and therefore offer a fragile connectivity which could, through a pen stroke on a budget, be taken away.

Within settlements, the aesthetic of place has deeply agentic properties. The visual landscape of the houses, streets and public spaces produce a homogeneity and sameness which has reverberating effects on daily life and urban culture. The 
sameness of RDP housing in some resettlement areas and of tin shacks in places like Lotus Park, or the blandness of streetscapes without vibrant commercial and public activity, is not unconnected to low morale and perpetual resentment, foregrounded by the perpetual micro-protests which are a daily occurrence in township life. In this uniformity, the inertia reinforced by the visual landscape envelops interventions trying to alter the dynamic of place, such as VPUU's Active Boxes or its public space experiments in Lotus Park, or the airy and serene Madrassa in Blikkiesdorp. This material sameness works to contain the innovation and excitement, be it from NGOs or community members.

Similarly, in new occupations, the particular aesthetic of places, pieced together from scratch, quickly gets enrolled in the making of the social order and its collective affects. If in its short duration Symphony Way became a model small community run in a democratic way, this was because of the shared feelings between the 150 protesting families, the support of activists and media engagement, and the style and strength of the leadership that emerged. But the topography - the barricade on a highway, the collectively-built shacks, the spaces cleared for meetings and recreational activities, the unlocked doors, the walks into Delft to get water - also played its part in inculcating a sense of common cause and togetherness. In Marikana Informal Settlement, as the occupation unfolded in late 2014, its visual landscape sand dunes with dispersed shacks, dangerous electricity cables lying on the ground, resident gatherings in open space, hastily assembled legal campaign meetings, the landowner's house nearby, daily crossings of the busy highway to find water - was unmistakably part of the governance arrangements: an improvised stage and medium of hesitant but consultative deliberation.

In Cape Town's informal settlements and townships, the landmarks - market stalls, bars, restaurants, shops, road intersections, open spaces, taxi ranks, and more - are as much implicated in governance as they are in providing social and economic services. Maphindi's Butchery in Nyanga, the crossing bridge over Lotus River in Lotus Park, and the parking lot in one of Du Noon's primary school are landmarks which people can use to orient and place themselves and connect with other people. With so much of local life played out in the dense public sphere - only thinly separated from the private, landmarks effect the forms of social ordering.

Flows, the character and quantity of matter passing through a system, also form the arrangements of governance. From the MyCity bus stop in Du Noon to the taxi rank in Nyanga, people arrive in places and make their way through settlement network. This flow is most heavy in the early morning and late in the evening, adding two hours to the conventional 'rush hour' as employers have little empathy for the distance. The material flows of services, electricity, sewage, and the like, stops short of the last mile' (as transport experts call it), ending in communal taps or in other people's homes. This last mile, where the flow stops short, is where fragile networks of extension and improvisation are built. 
More straightforwardly, the force of 'matter as government' is evident in how trunk infrastructures - their services and technologies - meet basic needs as well as shape social expectations. In the big cities, including Cape Town, infrastructures are sensed as the material of power, profits, rake-offs and uneven distribution and as the test bed of social progress in the new nation (McLennan, 2007). Thus, for example, in the RDP settlements residents know that state contractors cut corners in servicing the houses, sometimes even omitting to install services or provide title deeds. Backyarders and illegal settlers, without access to water and electricity, turn to quiet piracy, willing neighbours, informed advocates, and legal loopholes to get what they can, often opposed by local resident groups and political organisations. NGOs like CORC or VPUU, proposing infrastructural alternatives that require community input, battle with resident expectations that the state will provide, while cobbling through messy and contested processes of participation. 'Benign bureaucrats know that state provisioning will have to become both more comprehensive and more partnershipbased in order to meet the ever-mounting demand for basic services in the city. However, they also know that 'supply-driven' approaches are easier to manage. Though not expressed in these terms, there is a distinctive sense that infrastructures are political, their configurations decisive in the experience of urban citizenship and the evolution of the social contract between the city and urban dwellers.

Though the politics of infrastructure may be sensed primarily as a politics of uneven distribution, it has its other hidden dimensions, for example, the social enrolments of often visibly raw technologies (e.g. hanging cables, broken pipes, portable toilets in serried rank). In Marikana there is the threat of electricity cables lying on the sand dunes and of the busy highway that has to be crossed to obtain water. In some ways, these hardships have served to foster a sense of fragmented but shared purpose, the manifestation of which is the political amalgamation of two settlements (Marikana 1 and Marikana 2) into one cause. In Lotus Park, VPUU's efforts to public spaces and service points into community reinforcing political technology is confronted by shacks with little to no services, badly maintained communal water taps and impassable alleys on a daily basis. VPUU is clearly aware of the possibilities associated with an altered material culture, though equally aware of how many embedded settlement technologies reinforce apathy and individualism. The balance can alter though. In Du Noon and Nyanga, where the infrastructural landscape has become ever more variegated with time, ranging from conventional subsidized houses to improvisations made by a whole range of actors, municipal attempts to improve public spaces and facilities have stuck more firmly to the urban landscape.

In sum, the social force of cartographies, aesthetics, flows and infrastructures of Cape Town's settlements is significant. Clearly, this force is not independent of the policy decisions and social mobilisations that have shaped them in the first place. But as the preceding discussion has shown, settlement materials possess a life of their own, shaping social prospects, affinities and orientations from close up, a capacity that has 
to be understood as a form of socio-technological governance. This dual character both opens the scope for social improvement through a politics of settlement aesthetics, layout and public provisioning, as well as restricts its reach to the extent that ingrained material orderings have their own say. There is a challenge of alignment between material culture and policy intervention posed by this dualism, requiring the agency of things to be made visible, made a matter of social interest, and subjected to resolute intervention.

\section{Prospects}

Here we propose prospects for Cape Town's future, with implications for housing and informal settlement policies in developing cities. Second, we discuss the implications for urban theory, in particular the value of socio-technical studies of southern cities.

In Cape Town - and South Africa in general - the mechanisms in place to address the needs of the poor are more robust than in most developing countries. The Constitution and supporting legal and policy frameworks commits to social equity, opportunity and empowerment: in short, undoing the apartheid legacy and meeting socio-economic needs. There is a high expectation for social justice among the historically disadvantaged non-white population and their allies. The knowledge and institutional base for critical analysis and policy reform and delivery is in place. There is ample associational life in the informal settlements as well as popular mobilisation for land, housing, work and welfare for the poor. There is an evolving welfare state and a developed human settlement programme at state and municipal level. Undeniably, the national and local government is providing scaled resources to meet the needs of the urban poor. While these investments in housing and services remain small in comparison to that which is invested in wealthy areas (see McDonald's, 2012, critique of inequality in Cape Town), they have undeniably resulted in a much smaller proportion of households living in inadequate conditions than in many African cities, many in the lowest-income quintiles owning urban land and housing, and the production of a huge amount of affordable housing stock which the market alone would have never provided, and livelihood opportunities (in the form of petty landlordism) for millions. For this, it is impossible to see this regime as purely neoliberal (Parnell and Robinson, 2012).

However, the paradox is clear. These efforts to meet the needs for housing have had material, social, and political implications. As we have endeavoured to show, the ways in which progressive policies, grounded practices, and materiality come together, creates complex socio-technical configurations. They reflect many actor networks human and nonhuman, organised and improvised, intentional and non-intentional implicated in the governance of informal settlements and the lives of their residents, always distorting the policy blueprint. These configurations - or assemblies or dispositifs - leave many frustrated and marginalized. They reflect plural interests and designs that cannot be contained or satisfied within even the most collaborative and 
inclusive of city planning procedures. They often leave little room for meaningful manoeuvre, and where room does exist, it caters directly towards more individualized forms of improvising.

To acknowledge this is not to devalue the City's human settlements programme, or any of the other national or provincial efforts to reverse the legacy of apartheid or meet basic needs. The authorities - in particular the benign bureaucrats who work day in and day out in informal areas - are well aware of the conflicts and contradictions at stake. So too are they aware of the limits of blanket policy actions, the value of plural, negotiated and situated interventions, and the difficulties of integrating remote places into city life ${ }^{6}$. Rather, it is to consider the implications of practices and materials for the making of places and the inability of the state, no matter how strong, to control all aspects of urban life. How can we reframe these practices, not as aberrations of otherwise good plans and policies, but as fundamental to the realizing of South Africa's social contract? How can we crack open the engineering guidelines, the traffic flow equations, and the construction regulations to make space for the politics and power of the material infrastructure to emerge and support, despite the possible contradictions this might create?

In addressing these questions, there is a need to engage with operative plualism. Public authorities need to consider the implications of settlements becoming heterogeneous entities like the old townships, developing multiple housing forms, mixes of ownership and rental occupancy, different kinds of commercial activity, variegated social and occupational structures, and diverse infrastructural assemblages. Such heterogeneity stands in the way of managing informal settlements and townships in top-down and singular ways, as interventions jostle with NGOs, social movements, local associations, political groups, influential individuals, organised interests, and material assemblages. This pluralism is not intrinsically better at reaching those most in need, for its coverage can be patchy, inconsistent, against the interests of the underrepresented, and quickly appropriated by capitalism and market forces (Pieterse and Simone, 2014). But it poses a legitimate question about how the state can be most effective - whether for example interventions focusing on the urban commons, such as investing in and maintaining public spaces, services and utilities, or ensuring access to affordable housing, welfare and basic income, might be more effective than focusing on providing free housing (Lemanski, 2010). These tensions, on the back of a declining fiscus and the pervasive expansion

\footnotetext{
6 This is not say that there is no room for policy reform. The evidence here suggests a number of possibilities: paying more attention to the aesthetics, public spaces and services of settlements, old and new; subsidising NGO or community-based initiatives rather than simply collaborating with them; placing less emphasis on new build and owner occupation and more on in-situ upgrading, mixed housing forms, and a regulated rental market; embarking on a programme of land acquisition and refurbishment in the city's inner areas; exploring legally legitimate ways of delivering services and amenities to land occupations by the homeless and poor; and buttressing community initiatives struggling against vested interests.
} 
of the logic of capital within settlement, city, country and international circuits, remain critical challenges that have to be reckoned with. .

Herein lies the rub. In the new South Africa, the state violence of Apartheid has given way to the violence of a neoliberal democracy, with all its market misallocations and private appropriations. Stepping up and reforming state protections for the poor and for informal settlements (along with buttressing NGOs and social movements) can achieve only so much if markets and owners are given a free hand, congesting the transport infrastructure and escalating commuting costs, shedding labour, keeping wages down and maintaining a massive reserve army of labour, buying up and inflating the price of prime real estate, neglecting social and spatial need if unprofitable, and in general sharpening the divide between the haves and haves not. For every effort made to improve the informal settlements and the lives of those living in them, the neoliberal political economy raises barriers for the latter in the form of monopoly and privatisation, rising costs, unemployment, poor and temporary work, long and costly commutes, rudimentary provisions and infrastructures, and terrible living conditions.

Recognising the agency of materiality, improvisation, and citizens, thus, cannot be at the expense of rigorous effort to understand and dismantle a driving productive force in the making of inequality and subjectivity in South Africa, as underlined by leading South African urban scholars such as Patrick Bond, Marie Huchzermeyer, Edgar Pieterse and Sue Parnell. But, as we have tried to show, the political economy of state organisation for the poor or for capital fixes onto space and material life new configurations of governance that are difficult to separate into clear categories. The incorporation of materiality and social practice into the study of governance in South African townships and informal settlements brings light and life to these configurations. It reveals both the conjunctural nature of their production and the opportunities for their reconfiguration through hybrids of policy and everyday organisation sitting uncomfortably with received categories of policy responsibility.

\section{Acknowledgments}

We are grateful to Professor Edgar Pieterse for his generosity and support. We are also thankful to the many interviewees and informants who offered us insights into their lives and spaces. We are particularly grateful to Sizwe Mxobo, who shared his experience and expertise and assisted greatly with the fieldwork.

\section{References}

Amin, A (2014) 'Lively infrastructure', Theory, Culture and Society, 31, 7/8: 137-61. Amin, A and N Thrift (2016) Seeing Like a City: Cambridge, Polity. 
Baker, J (2008) Urban Poverty: A Global View, Washington DC, World Bank, Urban Papers (5).

Bénit-Gbaffou, C and S Oldfield (2011) 'Accessing the state: everyday practices and politics in the south', Journal of Asian and African Studies, 46, 5: 445-453.

Bickford-Smith, V, van Heyningen, E, and N Worden (1999). Cape Town in the twentieth century: an illustrated social history, Cape Town, New Africa Books.

Björkman, L (2015) Pipe Politics, Contested Waters: Embedded Infrastructures of Millennial Mumbai, Durham, NC, Duke University Press.

Boal, A (1998) Legislative Theatre: Using Performance to Make Politics, London, Routledge.

Bond, P (2000) Cities of Gold, Townships of Coal: Essays on South Africa's New Urban Crisis, Trenton, Africa World Press.

Bond, P and A Tait (1997) 'The failure of housing policy in post-apartheid South Africa' , Urban Forum, 8, 1: 19-41.

Boo, K (2012) Behind the Beautiful Forevers, London, Random House.

Bradlow, B (2015) 'Quiet conflict: institutional change, informal settlements upgrading, and formalized partnerships between local authorities and urban social movements in South Africa'. In Herrie, P, Ley, A and J Fokdal (eds.) From Local Action to Global Networks: Housing the Urban Poor London, Routledge.

Caldeira, T (2000) City of Walls: Crime, Segregation and Citizenship in Sao Paolo, Oakland, CA, University of California Press.

Cirolia, L, Smit, W and J Duminy (2015) 'Grappling with housing issues at the city scale: mobilising the right to the city in South Africa. In Herrie, P, Ley, A and J Fokdal (eds.) From Local Action to Global Networks: Housing the Urban Poor, London, Routledge.

Cirolia, L R, Görgens, T, van Donk, M, Smit, W, and S Drimie (Eds.) (2016) Pursuing a Partnership Based Approach to Incremental Informal Settlement Upgrading in South Africa, Cape Town, University of Cape Town Press.

City of Cape Town (2012) Integrated Human Settlements - Five-Year Strategic Plan, City of Cape Town.

Croese, S, Cirolia, L R, and N Graham (2016) 'Towards Habitat III: Confronting the disjuncture between global policy and local practice on Africa's 'challenge of slums", Habitat International, 53: 237-242.

De Boeck, F and S Baloji (2016) Suturing the City: Living Together in Congo's Urban Worlds, London, Autograph.

Dierwechter, Y (2004) 'Dreams, bricks, and bodies: mapping 'neglected spatialities' in African Cape Town', Environment and Planning A, 36: 959-981.

Ernstson, $H$ (2013) 'Re-translating nature in post-Apartheid Cape Town: the material semiotics of people and plants at Bottom Road.' In R Heeks (ed.) ActorNetwork Theory for Development, Working Paper Series Paper 4/2013. Manchester, Institute for Development Policy and Management, SED, University of Manchester.

Gandy, M (2014) The Fabric of Space. Water, Modernity, and the Urban Imagination, Cambridge, MA, MIT Press. 
Gilbert, A (2004) 'Helping the poor through housing subsidies: lessons from Chile, Colombia and South Africa', Habitat international, 28, 1: 13-40.

Graham, S and C McFarlane (eds.) (2014) Infrastructural Lives: Urban Infrastructure in Context, London, Routledge.

Hansen, T B (2012) Melancholia of Freedom: Anxiety, Race and Everyday Life in a South African Township, Princeton, NJ, Princeton University Press.

Harber, A (2011) Diepsloot, Johannesburg, Jonathan Ball.

Harrison, P, Todes, A. and V Watson (2008) Planning and transformation: Learning from the Post-Apartheid Experience, The RTPI library series, London, Routledge.

Heller, P (2012) 'Democracy, participatory politics and development: Some comparative lessons from Brazil, India and South Africa', Polity, 44, 4: 643-665.

Holston, J (2008) Insurgent Citizenship: Disjunctions of Democracy and Modernity in Brazil, Princeton, NJ: Princeton University Press.

Huchzermeyer, M (2003) 'Low income housing and commodified urban segregation in South Africa'. In Ossenbruegge, J and C Haferburg (eds.) Ambiguous Restructurings of Post-Apartheid Cape Town - The Spatial Form of Sociopolitical Change, Muenster, Hamburg and London, LIT Verlag.

Huchzermeyer, M (2011) Cities with Slums: From Informal Settlement Eradication to a Right to the City in Africa, Cape Town, Juta Academic.

Heynen, N, Kaïka, M and E Swyngedouw (eds.) (2006) The Nature of Cities: Urban Political Ecology and the Politics of Urban Metabolism, London: Routledge.

Jaglin, S (2014) 'Rethinking urban heterogeneity'. In Parnell, S and Oldfield, S (eds.) The Routledge Handbook on Cities of the Global South, London, Routledge, 434446.

Jürgens, U, Donaldson, R, Rule, S, and J Bähr (2013) Townships in South African cities-literature review and research perspectives', Habitat International, 39 : 256-260.

Khan, F and P Thring (eds.) (2003) Housing Policy and Practice in Post-apartheid South Africa, London, Heinemann.

Lancione, M (2014) 'The spectacle of the poor. Or: 'Wow!! Awesome. Nice to know that people care!', Social and Cultural Geography, 15: 693-713.

Larkin, B (2013) 'The politics and poetics on infrastructure', Annual Review of Anthropology, 42: 327-43.

Lemanski, C (2010) 'Moving up the ladder or stuck on the bottom rung? Homeownership as a solution to poverty in urban South Africa, International Journal of Urban and Regional Research, 35, 1: 57-77.

Ley, A (2010) Housing as Governance: Interfaces between Local Government and Civil Society Organisations in Cape Town, South Africa, Muenster, Hamburg and London. LIT Verlag Münster.

Mafukidze, J K and F Hoosen (2009) 'Housing shortages in South Africa: a discussion of the after-effects of community participation in housing provision in Diepkloof', Urban Forum, 20: 379-396. 
McCann, B (2013) Hard Times in the Marvelous City: From Dictatorship to Democracy in the Favelas of Rio de Janeiro ${ }_{2}$ Durham, NC: Duke University Press.

McDonald, D. A. (2012) World City Syndrome: Neoliberalism and Inequality in Cape Town, London, Routledge.

McFarlane, C (2011) 'Assemblage and critical urbanism', City, 15, 2: 204-25.

McFarlane, C (2012) 'The entrepreneurial slum: civil society, mobility and the coproduction of urban development, Urban Studies, 49, 13: 2795-2816.

McFarlane, C (2013) 'From sanitation inequality to malevolent urbanism: the normalisation of suffering in Mumbai', Geoforum, 43:1287-1290.

McFarlane, C, and J Silver (2016) 'The poolitical city: "seeing sanitation" and making the urban political in Cape Town', Antipode.

McGaffin, R, Cirolia, L R, and M Massyn (2015) 'Overcoming the challenge of vertical consolidation in South Africa's low-income settlements: a case study of $\mathrm{Du}$ Noon', Urban Forum, 26, 1: 59-75.

McGaffin, R, Napier, M and L Gavera (2014) 'Value capture in South Africa conditions for their successful use in the current legal context, Urban Forum, 25, 3: 375-387.

McLennan, A (2007) 'The academic/practitioner interface in public administration: the early years - 1990 to 2000', Service Delivery Review, 6, 1: 40 - 46.

Neuwirth, R (2005) Shadow Cities, New York, Routledge.

Newton, C (2009) 'The reverse side of the medal: about the 2010 FIFA World Cup and the beautification of the N2 in Cape Town' Urban Forum, 20, 1: 93-108.

Ngxiza, S (2012) 'Sustainable economic development in previously deprived localities: the case of Khayelitsha in Cape Town, Urban Forum, 23, 2: 181-195.

Nuttall, J (1997) The First Five Years: The story of the Independent Development Trust, Cape Town, The Independent Development Trust.

Oldfield, S and S Greyling (2015) 'Waiting for the state: a politics of housing in South Africa', Environment and Planning A, 47: 1100-1112.

Parnell, S \& J Robinson (2012) '(Re) theorizing cities from the Global South: Looking beyond neoliberalism', Urban Geography, 33, 4: 593-617.

Pieterse, E (2013) 'Rethinking the purpose and modalities of community development in South African cities'. In Good Governance Learning Network (eds.) Active Citizenship Matters, Cape Town, Islanda Institute: 19-35.

Pieterse, E and A Simone (eds.) (2014) Rogue Urbanism: Emergent African Cities, Auckland Park, SA: Jacana.

Pieterse, E and L Cirolia (2016) South Africa's emerging national urban policy and upgrading agenda'. In Cirolia, L, Görgens, T, van Donk, M, Smit, W, and S Drimie (eds.) Pursuing a Partnership Based Approach to Incremental Informal Settlement Upgrading in South Africa, Cape Town, University of Cape Town Press, 553-565.

Posel, D (2010) 'Races to consume: revisiting South Africa's history of race, consumption and the struggle for freedom', Ethnic and Racial Studies, 33, 2: 157-175. 
Ross, F C (2010) Raw Life, New Hope: Decency, Housing and Everyday Life in a PostApartheid Community, Cape Town, Juta.

Roy, A (2005). Urban informality: toward an epistemology of planning. Journal of the American Planning Association, 71, 2: 147-158.

Roy, A (2011) 'Slumdog cities', International Journal of Urban and Regional Research, 35, 2: 223-38.

Sacks, J (2014) 'Sweet Home: a preliminary investigation into the socio-political character of recent road blockades by protesting shack dwellers in South Africa, Journal of Asian and African Studies, 49, 1:,115-125.

Saff, G (1996) 'Claiming a space in a changing South Africa: the "squatters" of Marconi Beam, Cape Town', Annals of the Association of American Geographers, 86, 2: 235-255.

Satterthwaite, D and D Mitlin (2014) Reducing Urban Poverty in the Global South, Routledge, London.

Scheba, S (2014) 'Overcoming water scarcity for good?: Querying the adoption of desalination technology in the Knysna Local Municipality of South Africa'. PhD thesis, ???.

Skuse, A and T Cousins (2007) 'Spaces of resistance: informal settlement, communication and community organisation in a Cape Town township', Urban Studies, 44, 5-6: 979-995.

Simone, A (2014a) Jakarta: Drawing the City Near. Minneapolis, University of Minnesota Press.

Simone, A (2014b) 'Relational infrastructures in postcolonial urban worlds'. In Graham, S and C McFarlane (eds.) Infrastructural Lives: Urban Infrastructure in Context, London, Routledge, pp. 17-38.

Symphony Way Pavement Dwellers (2011) No Land! No House! No Vote!: Voices from Symphony Way, Cape Town, Pambazuka Press.

Truelove, Y (2015) Gray zones: Water, Power and Practice in Everyday Delhi, Unpublished PhD Thesis, Department of Geography, University of Cambridge.

Steinberg, J. (2015). A man of good hope, Johannesburg, Jonathan Ball.

Turok, I and J Borel-Saladin (2015) 'Backyard shacks, informality and the urban housing crisis in South Africa: stopgap or prototype solution?', Housing Studies, 31, 4: 384-409.

UN-Habitat (2008) State of the World's Cities 2010/2011: Bridging the Urban Divide, Nairobi, United Nations Human Settlements Programme.

UN-Habitat (2012) State of the World's Cities 2012/2013: Prosperity of Cities, Nairobi, United Nations Human Settlements Programme.

Van Donk, M, Swilling, M, Pieterse, E, and S Parnell (2008) Consolidating Developmental Local Government: Lessons from the South African Experience, Cape Town, Juta and Company.

Harrison, P, Todes, A, and V Watson, (2007) Planning and Transformation: Learning from the Post-Apartheid Experience, London, Routledge.

Von Schnitzler, A (2016) Democracy's Infrastructure: Techno-Politics and Protest after Apartheid, Princeton, NJ, Princeton University Press. 
Watson, V (2012) 'Planning and the 'stubborn realities' of global south-east cities: Some emerging ideas', Planning Theory, 121: 81-100.

Wilkinson, P (1998) 'Housing policy in South Africa', Habitat International, 22, 3: 215229.

Wolff, H (2010) Online: http://informalcity.co.za/du-noon 


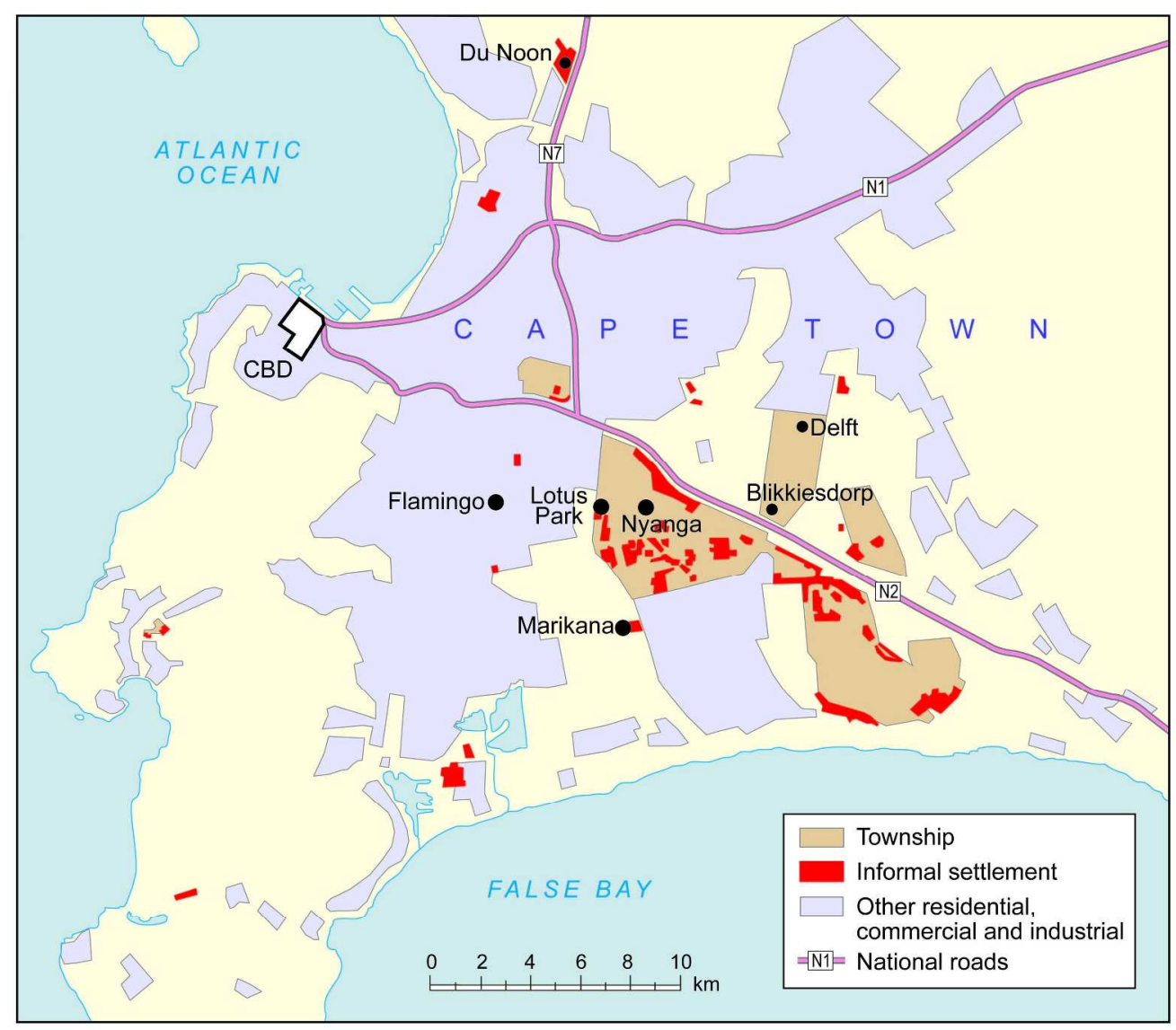

$1018 \times 891 \mathrm{~mm}(72 \times 72 \mathrm{DPI})$ 